\title{
Good Material: Canada and the Prague Spring Refugees
}

\author{
LAURA MADOKORO
}

\section{Abstract}

In August 1968, the Soviet Union sent troops into Czechoslovakia to crush the burgeoning spirit of reform known as the "Prague Spring." The Soviet invasion and the return of oppressive government measures triggered the flight of twenty-seven thousand people, eleven thousand of whom came to Canada. Using newly released archival records, this paper explores how the Canadian government approached the refugee crisis and argues that confident offcials, buoyed by a charismatic leader and operating in an era of improved East-West relations, manipulated the conventional definition of a refugee and consciously adopted policies that enabled large numbers of Czechoslovakian refugees to resettle in Canada.

\section{Résumé}

En août 1968, l'Union soviétique envoie des troupes en Tchécoslovaquie pour écraser l'esprit de réforme en plein essor dit du «Printemps de Prague. " L'invasion soviétique et le retour de l'oppression étatique ont entraîné la fuite de vingt-sept mille personnes, dont onze mille sont venues au Canada. À l'aide de documents d'archives nouvellement rendus publics, l'auteur étudie la réaction du gouvernement canadien à cette crise des réfugiés et soutient que les autorités, confiantes, soutenues par un leader charismatique et opérant dans une atmosphère d'amélioration des relations Est-Ouest, ont manipulé la définition acceptée de réfugié et consciemment adopté des politiques qui ont permis à grand nombre de réfugiés tchécoslovaques de s'installer au Canada.

In the wake of the 1968 invasion, the vast majority of the newcomers to the West did not undergo the risk of combating the Iron Curtain in the darkness of the Sumava forest; rather they arrived with passports and often by car, fully loaded. ${ }^{1}$

\section{Introduction}

In August 1968, Canadian prime minister Pierre Trudeau was vacationing in Spain, enjoying the warm sun and savouring the fine food of the region. In a very different part of Europe, Soviet and Warsaw Pact troops were massing on the borders of Czechoslovakia, preparing to put an end to the period of blossoming freedom and intellectual ferment known as the "Prague Spring." The Soviet invasion was a brutal reminder that the Cold War conflict, which seemed to have abated with the rise of détente in the early 1960s, had not yet been resolved. The invasion caused the flight of many thousands of Czechoslovakians and invited the possibility that Canada, and its allies in the North Atlantic Treaty Organization (NATO), would respond militarily to the violence. What would Canada do? Would it go to war to protect the borders of an independent nation? Would it help the refugees? The first option was never seriously considered but the issue of refugees framed much of the debate around the Canadian response to the crisis. This article explores how the Canadian government approached the refugee crisis in 1968 and argues that officials, buoyed by a charismatic leader and operating in an era of improved East-West relations, manipulated the conventional definition of a refugee and consciously adopted policies that enabled large numbers of Czechoslovakian refugees to resettle in Canada.

In doing so, this article takes the concept of "agency" and applies it to state officials rather than the migrants who were subject to their decisions. For the past ten years, scholars have revised the historic representation of refugees, turning to categories of analysis that acknowledge greater decisionmaking agency on the part of those individuals who choose to abandon situations of violence, poverty, and inequality. ${ }^{2}$ This emphasis on choice has caused the traditional image of the persecuted refugee to be replaced with someone who, rather than being forced to leave, makes a conscious decision to do so. ${ }^{3}$ Increasingly, the line between an economic 
migrant (someone who moves for employment or business opportunities) and a refugee is blurring: "technically, refugees flee to save their lives, and migrants to improve their economic prospects; but distinguishing between them becomes difficult when people flee from countries where poverty and violence are direct consequences of the political system." "This article argues that governments, along with migrants, contribute to this convergence with implications for how countries of resettlement perceive, and prepare for, potential migrants. As a result, refugee agency must be understood against the reality that regardless of how much an individual can manipulate official categories of migration for their own purposes, the ultimate decision regarding their legal entry and resettlement still rests with the nation-state.

The movement of people from East to West between 1945 and 1989 provided an opportunity for committed anti-Communist governments to score strategic propaganda victories. Mass refugee movements, individual asylum seekers, and celebrated exiles were exploited to demonize repressive regimes in the Eastern bloc and simultaneously demonstrate the greatness of democratic societies. Governments in Western settler countries such as Canada, Australia, and the United States, with long traditions of using immigration policy to build nations in their own image, responded to the plight of the refugees based on the twin desires to communicate a message on the world stage and to advance the economic and social development of their nations. When the Soviet Union invaded Hungary in 1956, it created the first major exodus of "freedom fighters" to the Western bloc. Canada arranged for the transportation and settlement of thirty-seven thousand Hungarians in the largest single refugee movement to the country up to that point. It was a huge humanitarian effort and a major propaganda victory.

A decade later, the "Cold War refugees" of 1968 were seen quite differently by countries in the West. In Canada, officials viewed the "refugees" through the generous and optimistic lens of accommodation with the Soviet Union and stepped back from using the humanitarian crisis for propaganda purposes. Based on new archival evidence, this article shows how aid was extended based on national interests defined predominantly by labour and economic needs. ${ }^{5}$ Discussions amongst officials in the Departments of Manpower and Immigration and External Affairs show that moderate views of the Soviet Union and a pragmatic view of migration policy as enshrined in the newly minted 1967 Immigration Act determined the nature of Canadian aid to the Czechoslovakians who fled the Soviet violence in 1968. In the process, the very essence of who, and what, the Canadian state considered a refugee was transformed.

\section{Conceptualizing Choice}

The legal concept of a refugee emerged after the Second World War when organizations such as the Intergovernmental Committee on European Migration (ICEM) and the United Nations High Commissioner for Refugees (UNHCR) were established to deal with the fallout of millions of displaced people. Concern for and a desire to protect the most vulnerable of people encouraged the growth of an international refugee regime, which was enshrined in the 1951 United Nations Convention relating to the Status of Refugees (Refugee Convention) and the associated 1967 Protocol. ${ }^{6}$ The term "Convention Refugee," which places the onus on individuals having a "fear of persecution" to merit resettlement, has been manipulated by countries since its introduction, interpreted according to each signatory's legislative framework. In some countries entire bureaucracies have sprung up, dedicated solely to implementing the Convention. In others, only certain aspects of the Convention have been incorporated into national immigration laws, often in an ad hoc manner. ${ }^{7}$ In tandem with these changes, the ideological foundations of the Cold War that led to the initial categorization of a refugee have ebbed and flowed over the years, as has the implicit sense of persecution embodied in early postwar use of the term. In fact, the term has come to be seen by many interested parties as simply a convenient tool to access settlement in a foreign territory. ${ }^{8}$ The possibility of refugees posing some kind of threat, either as Communist infiltrators at the height of the Cold War, or more recently as resourceconsuming unskilled labour, has evolved concurrently. ${ }^{9}$

Earlier conceptualizations of people displaced by war and trauma cloaked individuals in tragedy and despair. ${ }^{10}$ After the Allied victory in Europe, refugee advocates masterfully exploited images of suffering and impoverishment to create a sensibility amongst the policy-makers and citizens in potential receiving countries that would facilitate the reception of refugees escaping the devastation on the Continent. ${ }^{11}$ Caring for refugees was transformed into a virtuous and noble undertaking, one that demonstrated compassion and generosity. Some scholars have even declared that a country's refugee policy defines its very character. In the words of Canadian academic Howard Adelman, "Refugee policy is the litmus test of the concept of justice in a society." 12

How states categorize migrant types has significant implications for how we understand the 1968 Czech movement and the Canadian state's response to crisis in the middle Cold War period. This article will show that the Czech refugees, long categorized as victims of Soviet violence and deserving of international humanitarian assistance, may not have actually fit this depiction and that, moreover, governments of the day knew this. This is a critical connection for if we rethink "refugee" as a category then, by necessity,

(C) Laura Madokoro, 2009. This open-access work is licensed under a Creative Commons Attribution-NonCommercial 4.0 International License, which permits use, reproduction and distribution in any medium for non-commercial purposes, provided the original author(s) are credited and the original publication in Refuge: Canada's Journal on Refugees is cited. 
we also need to review how nation-states deal with humanitarian crises.

Regardless of how much agency an individual possesses, the ultimate decision regarding their legal entry and resettlement rests with the nation-state. It is generally assumed that states are motivated to act out of self-interest, to obtain a benefit or reward or to fulfill a particular objective. ${ }^{13}$ Some scholars emphasize the significance of public opinion while others point to geopolitics as critical determinants in determining the nature of refugee aid. ${ }^{14}$ In Canada, there is an additional line of argument that suggests the federal Liberal Party (which was in office at the time of the 1968 crisis) is the natural governing party of the country. ${ }^{15}$ This political success is seen by many as stemming from the Liberals' historic ability to manipulate migration issues for electoral purposes. ${ }^{16}$ Its efforts in "courting the immigrant vote" are well documented. ${ }^{17}$ However, for a group to exercise influence on the political process they must be strategically important and this has never been the case for the Czech and Slovak communities in Canada. Dispersed across the country, often in sparsely populated districts, the communities' relationship with the Canadian state has never been an intimate one. In fact, it has often been subject to intense suspicion because of fears that the community's members were not committed to being "loyal Canadian subjects." ${ }^{18}$ The rationale for extending millions of dollars in aid and resettling twelve thousand Czechs following the Soviet invasion came from another source.

\section{History of the Czechs and Slovaks in Canada}

The earliest Czech and Slovak migrants were agricultural and manual labourers who came to Canada at the end of the 1880 s as settlement expanded westward. ${ }^{19}$ By the end of the First World War there were only six thousand Czechs and Slovaks in all of Canada. However the population grew dramatically in the interwar period to thirty thousand by 1931, largely due to turmoil at home and restricted access to the United States. ${ }^{20}$

In 1938, the community's numbers increased slightly when the Canadian government resettled 1,200 Sudeten Germans from Czechoslovakia, encouraged by funding and political pressure from the British government in London. ${ }^{21}$ In many ways, this earlier movement foreshadowed the decisions taken in 1968. Mackenzie King's government was determined to admit only a select group of refugees: "Many of these refugees ... were skilled craftsmen, professionals and farmers-exactly the kind of settlers Canada wanted ..."22 The end of the Second World War marked another convulsion in migration from Eastern Europe to Canada as thousands of people fled oppressive, unstable regimes for opportunities overseas. The 1961 census recorded 73,061 Czechs and Slovaks in Canada, almost half of whom were born overseas. Significantly, 72.9 per cent of Eastern European immigrants who came to Canada between 1946 and 1961 cited politics as the reason for their decision to migrate. ${ }^{23}$ Tight border controls imposed after the Communist coup in 1948 limited migration out of Czechoslovakia; however, the Canadian government did make a special effort to assist the "thousands of Czech officials caught on the wrong side of the Communist take-over." 24 This was both surprising given the government's fear of Communist infiltrators and understandable considering the great sympathy with which officials regarded the most "Western" of the Eastern European states. ${ }^{25}$ Despite this historic affinity, the Cold War damaged ties between Canada and Czechoslovakia. Relations became so strained that at times even the most routine and administrative of matters could give rise to diplomatic tensions. ${ }^{26}$ In 1954, members of the Czech community protested vigorously because they believed that Canadian authorities were preventing their families from joining them. Frustrated officials in the Department of External Affairs blamed the Czech government for refusing to issue visas and lobbied their counterparts in Prague to be more open. ${ }^{27}$

By 1968, Czech-Canadian relations were in a holding pattern. Canada had started selling wheat to the Eastern bloc in 1956 but ideologically the two nations were far apart. However, when changes in party leadership brought Alexander Dubček to power (replacing Stalinist-loyal Antonin Novotny) and Czechoslovakia's Communist leaders began to experiment with the idea of "socialism with a human face," Canadian officials became more hopeful. Excitement grew (both in Czechoslovakia and amongst observers in the Western bloc) as censorship rules were relaxed and a presidential amnesty was issued for all the victims of the Stalinist purges. There was a sense of real opportunity for change. ${ }^{28}$ The Soviets actually seemed prepared to allow some degree of liberalization until a group of intellectuals presented an indictment of the previous two decades of Soviet rule titled "Two Thousand Words." Incensed, the Soviet leadership decided to resort to violence to curb any further liberalization efforts. ${ }^{29}$ The Soviet Union, along with its Warsaw Pact allies, invaded Czechoslovakia on August 20, 1968. Thousands fled the country, including many of the intellectuals, writers, and artists who had participated in the exciting, heady days of the Prague Spring. ${ }^{30}$ Others, caught abroad at the time of the invasion, waited to see what would happen next. The government in Prague soon became one of the most orthodox and repressive Soviet satellites and many vacationers never returned home. Instead, they were joined by the 150,000 people who fled the country in the year following the invasion in search of resettlement opportunities abroad. Twenty years later, 
there was still one person crossing the border into Austria every four hours. ${ }^{31}$

\section{The Canadian Reaction}

Upon news of the invasion, Cabinet asked Prime Minister Trudeau to return from his holidays prematurely. Trudeau immediately agreed, offering to stop in London to discuss the situation with British prime minister Harold Wilson, but his ministers discouraged him. Cabinet wanted Trudeau to consult with them before visiting with heads of state abroad. ${ }^{32}$ Back in Ottawa, the prime minister led a response that was both cautious and strategic in its approach. Canada's NATO membership meant it had to consider the possibility of a military intervention if Soviet violence spread across Eastern Europe. The Canadian government wanted to avoid this situation so the government's official statement carefully tried to denounce Soviet tactics while avoiding suggestions that an aggressive Western response was in the works. The government condemned the invasion as "a flagrant breach of the principle of non-intervention" and called it a "tragedy for all people who prize human freedom and national independence." 33 The statement portrayed NATO's "ultimate goal" as "seeking a durable East-West accommodation." 34

Many Czechoslovakians were frustrated by the reaction of the West to the invasion of their homeland. The intellectual Ivan Svitak writes:

Among the international consequences of the Soviet invasion of Czechoslovakia was the hypocritical rhetoric of Western liberals, who did not move a finger in the critical situation, because they were fascinated by a bridge-building policy toward the Soviet Union .... Another, and the worst, consequence was the détente policy which rewarded Soviet aggressive postures with far-reaching concessions. The Soviet intervention worked in the short run, and history again seemed to confirm that the West has written off the Czechs and the other Central Europeans behind the Iron Curtain. ${ }^{35}$

The United States was alone in wanting to exploit the crisis to demonstrate NATO solidarity and commitments in Europe. To this end, it pushed the organization to broadcast a statement that would reaffirm its commitment to maintaining current troop levels in Europe. Trudeau refused to go along. ${ }^{36}$ Shortly after assuming office in the spring of 1968, his government had embarked upon a massive foreign policy review and he wanted to complete it before taking any new steps, or confirming any status quo positions, regarding Canada's NATO membership. ${ }^{37}$ Nevertheless, the Soviet invasion required at least some consideration by Canadian officials about what Soviet actions meant for international peace and security, and Canadian diplomats immediately engaged with the broader implications of the crisis.

For the most part, Canadian officials interpreted the Soviet Union's invasion as a sign of insecurity rather than belligerence. From his perch at the Canadian embassy in Moscow, Ambassador Robert Ford suggested that "it would be a mistake ... to interpret the Soviet invasion in Czech as prelude to a more aggressive military or political policy in Europe." 38 This was in tune with Trudeau's world view. While the prime minister was certainly not blind to the failings of Communism under Leonid Brezhnev, he was more sympathetic than many of his contemporaries to Soviet intentions. Instead of regarding their every act as evidence of aggressive expansion, Trudeau believed in respecting Soviet spheres of influence. ${ }^{39}$ This meant that Trudeau was unwilling to encourage or condone conflict (economic, political, or ideological) with Soviet authorities. According to one historian: "Pierre Trudeau loathed totalitarianism and the repression it meant for its subject peoples ... Yet Trudeau believed that in a world that was ideologically polarized, armed to the teeth and flirting with nuclear disaster, dialogue was preferable to confrontation." 40 These philosophical underpinnings and Trudeau's belief in the legitimate authority of governments (elected or otherwise) shaped his perceptions of the Soviet Union and its aspirations in the international arena.

In dissecting the thinking behind the invasion, Canadian officials concluded that the Soviets were trying to prevent any further liberalization within the Warsaw Pact. A week and a half after the invasion, senior officials in the Department of External Affairs completed a detailed analysis of the recent Soviet activity, in which they referred to "the emotionalism which has clouded Soviet judgment throughout the Czech affair" and the Russians' "extraordinary ignorance of the Czech realities." The memo concluded that the Soviet "position in East Europe is fundamentally weaker" because of the invasion and suggested, therefore, that the Soviet Union might become "less predictable." 41 Canadian diplomats worried about the state of affairs within both the Soviet Union and the Warsaw Pact generally in terms of the potential for greater conflict and violence. The Canadian government therefore adopted a policy of being as "unprovocative as possible," sensing that an "ideological breakup was taking place in Eastern Europe." ${ }^{2}$ The media and the Czech and Slovak communities in Canada called upon the government to pay attention to the plight of those caught behind the invasion. Ottawa resisted. Taking issue with editorials in the Globe and Mail in particular, officials told Mitchell Sharp, the Secretary of State for External Affairs: "We can facilitate the entry of Czech refugees to Canada; we cannot help them escape from Czechoslovakia. To pretend we can would only

(C) Laura Madokoro, 2009. This open-access work is licensed under a Creative Commons Attribution-NonCommercial 4.0 International License, which permits use, reproduction and distribution in any medium for non-commercial purposes, provided the original author(s) are credited and the original publication in Refuge: Canada's Journal on Refugees is cited. 
encourage false hopes and in fact make such escape more difficult." 43 As a result, the larger refugee situation and the Canadian response to it took some time to develop. Only when population flows into neighbouring Austria failed to abate weeks after the invasion did Canada look at the crisis from a more compassionate perspective.

Officials in the Department of External Affairs were the first to sound the alarm about a possible humanitarian crisis. On Labour Day weekend, recalled by some as "warm and sunshiny," Mitchell Sharp convened a gathering of senior bureaucrats from his department and a select few from the Department of Manpower and Immigration to discuss the "deteriorating situation." 44 The numbers of Czechs leaving the country continued to grow daily, and Sharp worried whether Austria was in a position to continue to absorb the flow from across the borders. In the recollections of some participants, the decision to provide refugee status to the Czechs came directly from the Secretary of State for External Affairs at this meeting. ${ }^{45}$ One official explains: "There was no cabinet memorandum, nor indeed any discussion among Ministers. Mitchell Sharp made the decision and I can only assume made his peace with the Prime Minister and Mr. MacEachen (Minister of Manpower and Immigration) after the fact." 46 External Affairs may have led the initial charge but determining the logistics for implementing the special program was left to the devices of senior officials in Manpower and Immigration.

\section{Offering Assistance}

After External Affairs made the decision to examine the refugee situation, immigration officials turned their attention to reports about the refugees themselves. There was tremendous reluctance on the part of Canadian authorities to refer to the Czech refugees as "freedom fighters." In fact, a number of scholars have pointed to how different the Czech refugees were from earlier movements. In her work on the operations of the UNHCR in this period Louise Holborn notes the difference between the "68ers" and earlier refugees from Czechoslovakia. The group was "composed of much younger people-students, teachers, scientists, journalists and doctors. Many of them spoke English, French and German. They were in possession of valid passports, and often had financial means." 47 Similarly, Gil Loescher has observed that "most of the people did not seek to apply for asylum immediately but preferred to wait and see how the situation evolved in Czechoslovakia before deciding on a course of action." International organizations hesitated to label the Czechs as refugees for fear of creating an "artificial refugee problem." ${ }^{48}$ It would look bad for everyone involved if somebody labelled a refugee opted to return home rather than be resettled. Canadian officials examined reports from
Vienna, which emphasized the migrants' levels of education and employment qualifications, and began to think about how the country could best respond to the situation. ${ }^{49}$ The key seemed to lie in the potential for the refugees to become important contributors to the Canadian economy.

The discussion around the economic potential of the Czech refugees was rooted in the broader shift in Canadian immigration policy in this period. Concerned about Canada's competitive edge, the federal government began to develop labour market policies in the early 1960 s to promote the growth of professional services, entrepreneurial ventures, and lucrative industries such as manufacturing and production..$^{50} \mathrm{~A}$ large supply of skilled labour was required. Canadian universities were growing exponentially, producing thousands of new graduates annually, but still the government remained concerned. One solution was to increase immigration numbers. This new philosophy was enshrined in the 1967 Immigration Act, which provided for a points system to determine eligible migrants to Canada. The selection system that was introduced stressed skills, education, and adaptability and removed discriminatory clauses against formerly penalized areas such as Asia. The very restructuring and renaming of the Department of Citizenship and Immigration to the Department of Manpower and Immigration showed the emphasis the government was placing on migrants as a source of labour. Recruiting skilled migrants was a competitive business. As Ather Akbari explains, there was a "general relative international scarcity of highly trained manpower" and "economic indicators within Canada suggested that the postwar economic boom was over" so migrants did not necessarily see the country as a destination of choice. ${ }^{51}$ As a result, the government was determined to use every opportunity to recruit skilled workers to Canada and the Czech crisis provided a nice opening, if it could be handled properly.

The Canadian government was drawn to the possibilities of acquiring highly skilled labour with the Czech refugees but at the same time, the archival records show that one of the major concerns for the government was managing the number of potential refugees. Officials in External Affairs cautioned that "political developments in Czechoslovakia may result in a much larger movement." 52 In other words, depending on how Moscow treated Dubček and what happened with border controls, the possibility of a larger exodus remained. In fact, Ottawa thought Moscow was "content to leave the borders fairly open so that liberal elements could eliminate themselves from the picture." 53 Canada was therefore loath to announce any grand resettlement scheme even though officials could barely disguise their interest in extending a helping hand to some of the Czech refugees, for they discerned tremendous economic potential in the

(C) Laura Madokoro, 2009. This open-access work is licensed under a Creative Commons Attribution-NonCommercial 4.0 International License, which permits use, reproduction and distribution in any medium for non-commercial purposes, provided the original author(s) are credited and the original publication in Refuge: Canada's Journal on Refugees is cited. 
highly skilled and well-educated numbers that were leaving the country.

Trudeau's government needed a strategy that would avoid encouraging a mass exodus, which would upset the Soviets and liberal elements in Czechoslovakia, and yet would allow it to obtain the highly skilled refugees it so brazenly coveted. Canadian policy was to be selective, designed to facilitate the movement of only particular refugees. ${ }^{54}$ Clever officials subsequently decided to apply the refugee definition to individuals who were outside of the country at the time of the invasion. This was a creative (mis)use of the legal definition of a Convention Refugee in order to give Canada's project in Austria greater legitimacy. Given that Canada only signed the Convention in 1969, officials had a fair bit of room to manoeuver on this front. One immigration officer recalls that he "had no problem with fudging the definition because the quality of the people who were asking to immigrate was so high." ${ }^{55}$ Ironically, Allan MacEachen, the Minister of Manpower and Immigration, referred to the importance of selecting "true refugees" but the government's approach revealed a willingness to create an inflated sense of humanitarian need in the interest of obtaining high-quality migrants. ${ }^{56}$

In all of the discussions about whether to assist the Czech refugees, the precedent set by the Hungarian refugees in 1956 loomed large. At the time, Prime Minister St. Laurent's Liberal government had provided free transportation to those who wanted to come to Canada and in 1968 Allan MacEachen pushed his colleagues to take similar action. There was a great deal of reluctance. Some ministers pointed out that the Czechs seemed to be more financially stable than many immigrants coming to Canada. They proposed to offer loans rather than grants but MacEachen accused them of hypocrisy. He maintained that it would be "morally and politically indefensible to draw such a distinction between current Czech refugees and those from Hungary in 1956." 57 Cabinet eventually concurred and agreed to offer free resettlement services to the Czechs, placing them in the same category as the Hungarian refugees who had received generous financial and moral support twelve years earlier.

On September 6, the government announced a limited program whereby it would issue visas for those Czechs interested in migrating to Canada according to the "relaxed standards traditionally offered to refugees." ${ }^{2}$ Normal requirements for sponsorship, potential employment, and financial assistance were waived. The government also set aside an initial \$2 million to cover the travel and settlement costs for an expected two thousand refugees. Immigration officials decided to use the nine selection factors that were inscribed in the 1967 Immigration Act as a guideline for selecting refugees. As one official explains, this gave "the selection officers a good deal of discretionary power." 59 The refugees Canada selected for resettlement were seen as "'good material': predominantly young and well educated." 60 Gerald Dirks and Michael Lanphier have both commented on the "high quality" of refugees that Canada recruited during this movement: 19 per cent of the household heads had more than twelve years of formal education and 33 per cent were either skilled or professional workers. ${ }^{61}$ Not wanting to risk the "survival of the Czech intelligentsia" 62 Canada declared from the start that its policy was to "accept but not recruit refugees." 63 However, the reality was that Canada was very interested in recruiting refugees and it proceeded to do so in Austria, in a manner that was hidden from both the Canadian public and Czech officials in Prague. The government was so successful in this vein that by October 1968 officials in External Affairs were able to report that the Czech government in Prague appreciated the "humanitarian, non-aggressive approach" and "accepted this as a concrete indication of (Canada's) moral support." 64

The day before making a public announcement about the special program for Czech refugees, Allan MacEachen asked his cabinet colleagues what they thought of having a team go to Europe "for the purpose of contacting refugees who were highly qualified in scientific and technological fields and who may be interested in coming to Canada." 65 The politicians who remembered the success of Jack Pickersgill's trip to Vienna at the time of the Hungarian Revolution embraced this suggestion. However, External Affairs was opposed to the plan, declaring that "it had the appearance of a gratuitous political gesture which could be taken by the Russians as a desire on our part to make "cold war" propaganda." 66 Despite this opposition, ambitions to secure the best talent before rivals like Australia and the United States could do so propelled the mission forward. ${ }^{67}$

In due course, a special delegation, headed by Andrew Thompson (Member of Parliament for Toronto-Dovercourt) and including representatives from the Canada Council, the National Research Council, and other professional bodies, was dispatched to Vienna. When questioned in the House of Commons about the ethics of taking the "cream" of the movement, MacEachen defended the team's mission, arguing that everyone was welcome to apply and the team was to "assist the specially qualified Czechoslovakians who may want to come to Canada by exploring with them the opportunities that are available in the country. There is no intention ... of taking any exclusive attitude toward any group of refugees." 68 Canada needed to sell itself and the special mission to Vienna was the best way to do it. Canada was well aware that migrants in Austria were gathering intelligence from each other about where the best place to resettle would be and learned to evaluate the many options that Western

(C) Laura Madokoro, 2009. This open-access work is licensed under a Creative Commons Attribution-NonCommercial 4.0 International License, which permits use, reproduction and distribution in any medium for non-commercial purposes, provided the original author(s) are credited and the original publication in Refuge: Canada's Journal on Refugees is cited. 
countries, desirous of their talent, offered them. One immigration officer recalls, "They met other like-minded refugees in Vienna and talked about 'destination options' and which country had the 'better offers." 69 Humanitarian assistance was a competitive venture. Australia accepted six thousand refugees while the United States facilitated the entry of just over eleven thousand. Given Canada's comparative size, it seems that its officials excelled at recruiting potential migrants.

Interest in securing the best migrants prompted the government to act quickly, and traditional concerns that marked earlier movements, such as security and threats of Communist infiltration, were generally considered in hindsight. ${ }^{70}$ The initial flow of refugees into Austria dwindled by October and Cabinet began to discuss ways of winding down the program. However immigration officials, who continued to monitor the situation in Vienna, noticed that very little of the two million dollars the government had set aside to assist the refugees had been used, so they began to envision ways to expand the program. They turned their attention to the possibility of enticing Czech students to come to Canadian universities and to facilitate their integration by providing language training. If any money was left over, officials argued that it could be disbursed to other Czech refugees for educational purposes. ${ }^{71}$ This was far above what immigrants normally received in support from the government; however, Allan MacEachen lobbied for this expanded policy, arguing that Canada had a special commitment to the Czech refugees because "they had been specially invited and assisted." 72 It seems the government wanted to continue to extend special invitations under the guise of alleviating a humanitarian crisis. The original two thousand spaces allocated for Czech resettlement multiplied to twelve thousand by the spring of 1969, in large part because the educated and skilled refugees proved to be such "good material."

\section{Coming to Canada}

The relative affluence of the Czech refugees is one of the many factors that points to the problems with the conventional and overly romantic depiction of a refugee as destitute and helpless. Most of the Czech refugees who came to Canada paid their own way or opted to take out loans to fund their voyage. The first to arrive flew into Toronto on September 15, 1968. They consisted of a group of 203 refugees, most of whom had friends and family in Canada. ${ }^{73}$ The Globe and Mail celebrated their arrival, profiling one "blond girl" in particular. According to the glowing article, she was " 22 , pretty, single and an architecture student. She wants to continue her studies in Canada." 74 The group was described in radiant terms: "as well dressed as any planeload of passengers getting off flights in Toronto, Montreal or New York" and "according to Immigration Department officials they include a small gold mine of talent."75 The first group of two hundred plus refugees included medical doctors, dentists, fifteen engineers, and two television set designers. Many of the refugees settled in Ontario although a significant proportion also made their way to the prairie provinces of Manitoba, Alberta, and Sasktachewan where earlier Czech immigrants had established themselves.

By all accounts, the integration of the Czech refugees occurred relatively smoothly. It seems that many sectors of society participated in their resettlement, as the Annual Report of the Department of Manpower and Immigration for 1968-69 draws special attention to the role that private organizations and individuals played in helping with the arrival of the Czech refugees. ${ }^{76}$ Behind the scenes, government officials continued to worry about the impact of the refugee movement on diplomatic relations with Czechoslovakia but for the most part the government's decisions did not affect the daily, lived experience of the Czechs in Canada. ${ }^{77}$ The other positive indicator was the high employment rate for the refugees even in the immediate period following their arrival. At the end of October, the Globe and Mail reported that over eight hundred refugees had found work, almost half in their own professions. ${ }^{78}$ A longitudinal study prepared by government found that the unemployment rate for the Czech migrants, after three years of being in Canada, was just above the national average (quite extraordinary considering the short time in which the refugees had been participating in the Canadian job market) and "a certain but only moderate occupation deflection in comparison with jobs held in Czechoslovakia." 79

One particularly telling statistic about the success of the program is how few Czechs returned to Czechoslovakia. Almost a year after the migrants arrived, only six hundred of the twelve thousand refugees had gone back. ${ }^{80}$ When individuals did decide to leave, the most vigorous attempts to dissuade them came from ardent anti-Communist Czech community organizations. The Masaryk Memorial Institute, which had been instrumental in settling thousands of Czech refugees in Ontario, tried to engage the government in preventing departures. In a lengthy petition, the Institute claimed that these refugees "made their decision to return to Czechoslovakia (during) a momentary feeling of depression and would probably be very sorry a few weeks after returning." They blamed Canadian authorities for raising false "expectations as to schooling and jobs and we are afraid that perhaps the problem of starting a new life in this country are not stressed strongly enough by our officials in Vienna." 81 Officials in Ottawa refused to curtail anyone's return home, even if it meant a possible propaganda victory for the Eastern bloc. For the government, the vast majority

(C) Laura Madokoro, 2009. This open-access work is licensed under a Creative Commons Attribution-NonCommercial 4.0 International License, which permits use, reproduction and distribution in any medium for non-commercial purposes, provided the original author(s) are credited and the original publication in Refuge: Canada's Journal on Refugees is cited. 
who were determined to stay in Canada was victory enough. And as the political scientist Reg Whitaker has noted, given that it cost the government less than $\$ 1,000$ to resettle each refuge, officials were probably quite pleased with the return on their investment. ${ }^{82}$ The only disconcerting element to all of this was that the movement was presented to the Canadian public as a humanitarian one, not a self-serving one.

\section{Conclusions}

As the first group of Czech refugees prepared to leave for their new homes, the Canadian representative in Vienna told them, "You have all reached a difficult and momentous decision ... Canada is glad to offer you a new home, but is saddened by the circumstances that have brought you to this step." He wished them "peace, contentment and a goodly measure of success, and especially may you establish a firm basis for the future of your children, in my country, which is so proud to welcome you!" 83 From the moment they conceived of a special program to assist Czech refugees, Canadian officials hoped that they would stay for the long term and make important contributions to the economic and social life of the country. ${ }^{84}$ These hopes translated into public statements that reassured Canadians that aiding the Czech refugees did not pose a threat to their economic welfare or political security and that the offer of relief was indeed a noble and virtuous undertaking. ${ }^{85}$ It was a carefully constructed charade, for Canadian officials also wanted to avoid embarrassing the Soviet Union during the crisis. There were many reasons for this subtle game of doublespeak but there is no doubt that the government communicated one message and acted on another. ${ }^{86}$

Politicians and scholars alike consistently reference the aid that Canada provided the 1956 victims of the Hungarian Revolution as a hallmark of generosity and selflessness. ${ }^{87}$ No similar mythology exists around the Czech refugee movement of 1968. Scholars have ignored it, as have the participants. Neither Mitchell Sharp nor Pierre Trudeau mention the movement in their memoirs. By contrast, Jack Pickersgill describes his intervention in the Hungarian crisis as the highlight of his time with the Department of Citizenship and Immigration. ${ }^{88}$ Perhaps it is difficult to be self-congratulatory when a movement serves ulterior motives. While the government spoke of saving refugees from "fear and persecution," 89 the decision to resettle refugees from Czechoslovakia was much more pragmatic than the rhetoric of the day implied. The Czech refugees were depicted as victims of the Soviet violence when, in actuality, Canadian officials were concerned less with Soviet behaviour and more with how they could secure skilled migrants for themselves. The "success" of the movement was measured not by how many lives were saved or how many families were reunited, but rather by employment rates and income levels.

It was also measured by how Canada fared vis-à-vis the Soviet Union in the international community. The nature of Canada's response to the 1968 invasion allowed it to maintain polite relations with the Soviet bloc so the spirit of détente could continue to grow all the while obtaining talented migrants under the guise of humanitarian aid. This required a liberal interpretation of what a refugee was.

In the case of the 1968 Prague Spring refugees, the Canadian government conceptualized of the refugees in terms of the new Cold War atmosphere so they were predisposed to avoid overly "victimizing" the refugees. This would have embarrassed the Soviet Union and possibly created a more volatile situation in Eastern Europe. The government was critical but not vengeful. When officials in Vienna began to report on the strengths of the refugees, specifically their professional qualifications and education levels, Canadian politicians realized that they had an opportunity to recruit thousands of skilled workers. The resettlement program served two purposes: it alleviated a humanitarian crisis and it allowed the country to benefit economically and socially from the influx of thousands of talented individuals. The Canadian government downplayed potential security risks and did not hesitate to manipulate the idea of a refugee for political and economic ends. The only victim was the traditional conception of what it meant to be a refugee in need of assistance.

\section{Notes}

1. Otto Ulc, "Those Who Left: A Current Profile," in The Prague Spring, ed. Jiri Pehe (New York: Freedom House, 1988), 147.

2. Lissa Malkki has argued persuasively for the importance of migrant agency; see "Refugees and Exile: From 'Refugee Studies' to the National Order of Things," Annual Review of Anthropology 24, no. 1 (1995): 495-523. Madeline Hsu deployed the idea of migrant agency to great effect in Dreaming of Gold, Dreaming of Home (Stanford: Stanford University Press, 2000).

3. Dariusz Stola, "Forced Migrations in Central European History," in "The New Europe and International Migration," special issue, International Migration Review 26, no. 2 (Summer, 1992): 324-341.

4. Gil Loescher, Beyond Charity: International cooperation and the Global Refugee Crisis (New York: Oxford University Press, 1993). 6.

5. Government records at Library and Archives Canada (LAC) were consulted extensively in the preparation of this article. In particular, records from RG 25 (Department of External Affairs Fonds) and RG 76 (Immigration Program Sous-Fonds) were used to excavate the behind-the-scenes

(C) Laura Madokoro, 2009. This open-access work is licensed under a Creative Commons Attribution-NonCommercial 4.0 International License, which permits use, reproduction and distribution in any medium for non-commercial purposes, provided the original author(s) are credited and the original publication in Refuge: Canada's Journal on Refugees is cited. 
discussions about what aid, if any, to offer the Prague Spring refugees. Interviews with former officials Allan Gotlieb, Gordon Barnett, and Michael Molloy were conducted for similar purposes.

6. The Convention relating to the Status of Refugees, penned at a moment of intense ideological conflict between East and West, allows anyone with a genuine fear of persecution to resettle outside their country of origin. The spatial and temporal limitations in the Convention were removed in the 1967 Protocol. Although Canada only ratified the Convention and the Protocol in 1969 (the delay stemmed largely from a fear of Communist infiltrators), the country applied the spirit of the Convention to its refugee policies since its inception.

7. Gil Loescher, The UNHCR and World Politics: A Perilous Path (Oxford and New York: Oxford University Press, 2001).

8. Randy K. Lippert, Sanctuary, Sovereignty, Sacrifice: Canadian Sanctuary Incidents, Power, and Law (Vancouver: University of British Columbia Press, 2005).

9. Catherine Dauvergne, Making People Illegal: What Globalization Means for Migration and Law (Cambridge and New York: Cambridge University Press, 2008).

10. Gil Loescher and John Scanlan, Calculated Kindness: Refugees and America's Half-Open Door, 1945 to the Present (New York: Free Press, 1986).

11. Michael Marrus, Unwanted: European Refugees from the First World War through the Cold War (Philadelphia: Temple University Press, 2002).

12. Howard Adelman, "Canadian Refugee Policy in the Postwar Period: An Analysis," in Refugee Policy: Canada and the United States, ed. Howard Adelman (Toronto: York Lanes Press, 1991): 172.

13. Matthew J. Gibney, "Liberal Democratic States and Responsibilities to Refugees," American Political Science Review 93, no. 2 (March 1999): 169-181.

14. Gary P. Freeman," Migration Policy and Politics in the Receiving States," International Migration Review 26, no. 4 (Winter 1992): 1144-1167; see also Loescher and Scanlan.

15. Reginald Whitaker, The Government Party: Organising and Financing the Liberal Party of Canada, 1930-58 (Toronto: University of Toronto Press, 1977).

16. Ninette Kelly and Michael Trebilcock, The Making of the Mosaic: A History of Canadian Immigration Policy (Toronto: University of Toronto Press, 1998).

17. Jack Jedwab, "Counting and Courting the Immigrant Vote: Will Canada's Foreign-Born Determine the Final Outcome of the 2004 Federal Election?" <http://www.acs-aec.ca/ oldsite/Polls/15-06-2004.pdf> (accessed April 8, 2008).

18. Reg Whitaker, Double Standard: The Secret History of Canadian Immigration (Toronto: Lester \& Orpen Dennys, 1987).

19. John Gellner and John Smerek, The Czechs and Slovaks in Canada (Toronto: University of Toronto Press, 1968), 74.
20. Ibid., 79. The authors point to the introduction of a quota system in the United States as the reason why Canada became an increasingly desirable destination.

21. Dirks, Canada's Refugee Policy: Indifference or Opportunism?, 74 .

22. Irving Abella and Harold Troper, None Is Too Many: Canada and the Jews of Europe (Toronto: Key Porter, 2000), 48.

23. Most viewed their move as a permanent relocation rather than short-term exile. Ibid., 80 .

24. Reg Whitaker, Double Standard, 77. The United States also made special efforts to assist victims of the coup. Approximately two thousand Czechs were granted admission in 1948. Loescher and Scanlan, 19.

25. Ibid., 77.

26. A similar situation arose five years later in 1973 when many "68ers" obtained citizenship and travelled back to Czechoslovakia on Canadian passports, assuming this guaranteed their protection. Canadian officials, worried that Czechoslovakia did not have a mechanism for renouncing citizenship, cautioned those who returned that "be they Canadian citizens or not" they were "subject to the full weight of the Czech legal apparatus, which could include prosecution for illegal emigration, and liability for the draft." Library and Archives Canada (LAC), RG 25, Volume 8640, file 20-1-2-CZECH, Political Affairs - Policy \& Background, Part 9, 1972-1973.

27. LAC, RG 25, Volume 4150, file 232-AX-40, Emigration from Czechoslovakia.

28. Joseph Rothschild and Nancy M. Wingfield, Return to Diversity: A Political History of East Central Europe since World War II, $3^{\text {rd }}$ ed. (Oxford: Oxford University Press, 2003), 170.

29. Joseph Skvorecky, a prominent writer and author, was one of the contributors to this manifesto. He fled to Canada where he and his wife founded Sixty-Eight Publishers, publishing almost two hundred works by Czech exiles. He was appointed a Member of the Order of Canada in 1992.

30. Jiri Pehe, ed., The Prague Spring (New York: Freedom House, 1988).

31. Ulc, 144

32. LAC, RG 2, Volume 6338, Privy Council Office, Cabinet Conclusions, August 21, 1968.

33. Canadian Annual Review of Public Affairs 1968, cited in Robert Bothwell and Jack Granatstein, Pirouette (Toronto: University of Toronto Press, 1990), 191.

34. LAC, RG 2, Volume 6338, Privy Council Office, Cabinet Conclusions, August 21, 1968.

35. Ivan Svitak, "The Premature Perestroika," in Pehe, Prague Spring, 147.

36. LAC, RG 2, Volume 6338, Privy Council Office, Cabinet Conclusions, August 30, 1968.

37. This review caused Canada's NATO allies great concern.

38. LAC, RG 25, file 20-CZECH-1-3-USSR, Czech-political affairs.

39. Bothwell and Granatstein, 190. 
40. Robert Wright, Three Nights in Havana (Toronto: HarperCollins, 2007), 91.

41. LAC, RG 25, file 20-CZECH-1-3-USSR, Czech-political affairs.

42. LAC, RG 2, Volume 6338, Privy Council Office, Cabinet Conclusions, August 28, 1968.

43. LAC, RG 25, Volume 8907, file 20-CZECH-1-3-USSR Czech-political affairs.

44. Joe Bissett, "The Czechoslovakian Refugee Movement, 1968," CIHS Bulletin: The Newsletter of the Canadian Immigration Historical Society, Issue 46 (July 2005): 2.

45. Ibid., 2 .

46. Ibid., 2.

47. Louise Holborn, Refugees: A Problem of Our Time: The Work of the United Nations High Commissioner for Refugees, 1951-1972, vol. 1 (Metuchen, NJ: Scarecrow Press, 1975), 516-517.

48. Loescher, The UNHCR and World Politics, 178.

49. LAC, RG 25, file IM 5782-1 Refugees - Czechoslovakian Movement - General File, Part 1.

50. Freda Hawkins, Canada and Immigration Public Policy and Public Concern / (Kingston, Ont.: McGill-Queen's University Press, 1988), 139.

51. Ather Akbari, "Immigrant 'Quality' in Canada: More Direct Evidence of Human Capital Content, 1956-1994," International Migration Review 33, no. 1 (Spring 1999): 157.

52. LAC, RG 25, file IM 5782-1 Refugees - Czechoslovakian Movement - General File, Part 1, Director General of Operations to Regional Directors, 5 September 1968.

53. LAC, RG 76, file 555-54-531, Memorandum to the Minister "Possible Modification of Czechoslovakian Refugee Program," October 15, 1968.

54. LAC, RG 25, Volume 20, File CZECH-1-3-USSR Czech - political affairs, 8907, Belgrade to Ottawa, August 30, 1968.

55. CIHS Bulletin, Issue 46, July 2005: 8.

56. LAC, RG 2, Volume 6338, Cabinet Conclusions. September $5,1968$.

57. LAC, RG 2, Volume 6338, Privy Council Cabinet Conclusions. September 10, 1968.

58. Dirks, Canada's Refugee Policy: Indifference or Opportunism?, 233.

59. Bissett, 3 .

60. LAC, RG 25, file IM 5782-1 Refugees - Czechoslovakian Movement - General File, Part 1, Couillard to Minister, 4 September 1968.

61. C. Michael Lanphier, "Canada's Response to Refugees," in "Refugees Today," International Migration Review 15, no. 1/2, (Spring-Summer,1981): 114; Gerald Dirks, Canada's Refugee Policy: Indifference or Opportunism? (Montreal: McGill-Queen's University Press, 1977), 233.

62. LAC, RG 25, Volume 8907, file 20-CZECH-1-3-USSR Czech - political affairs.
63. LAC, RG 76, file 555-54-531, Memorandum to the Minister "Possible Modification of Czechoslovakian Refugee Program," October 15, 1968.

64. LAC, RG 76, file 555-54-531, Memorandum to the Minister, "Possible Modification of Czechoslovakian Refugee Program," October 15, 1968. Officials also reported that Canada's approach made it the most popular foreign country in the post-invasion period.

65. LAC, RG 2, Volume 6338, Cabinet Conclusions. September $5,1968$.

66. LAC, RG 25, file IM 5782-1 Refugees - Czechoslovakian Movement - General File, Part 1, Halstead to Brown, 5 September 1968.

67. LAC, RG 25, file IM 5782-1 Refugees - Czechoslovakian Movement - General File, Part 1, Couillard to Minister, 4 September 1968.

68. Canada, Parliament, House of Commons, House of Commons debates. Débats de la Chambre des communes (Ottawa: Queen's Printer, 1968), September 19, 1968.

69. CIHS Bulletin, Issue 46, July 2005: 8.

70. LAC, RG 2, Volume 6338, Privy Council, Cabinet Conclusions, September 10, 1968. Howard Adelman has described the Canadian response to the Czech refugees as "overtly shaped by Canadian economic policies." See Adelman, "Canadian Refugee Policy in the Postwar Period," 193. Adelman notes a simultaneous decline in concern with security issues, "though Cold War ideology remained an important factor on a different plane."

71. LAC, RG 2, Volume 6338, Privy Council Cabinet Conclusions, October 3, 1968.

72. Ibid.

73. LAC, RG 25, file IM 5782-1 Refugees - Czechoslovakian Movement - General File, Part 2.

74. Globe and Mail, September 16, 1968, A1.

75. Ibid., A1.

76. Canada, Department of Manpower and Immigration, Annual Report of the Department of Manpower and Immigration. (Ottawa: 1969), 11.

77. Throughout the duration of the special program, discussions with Czechoslovakia focused on demands for the repatriation of particular individuals. Ottawa became concerned after reports surfaced in Prague that the family members of one of the refugees in Canada were being harassed in an attempt to force his return. Canadian officials refused to support this, citing the dangerous precedent that would be created. LAC, RG 25, Volume 8560, file 20-1-2-CZECH, Political Affairs - Policy \& Background, Part 5. Oct.68Apr.69, External Affairs to Prague, August 30, 1968.

78. Globe and Mail, October 24, 1968, A9.

79. Lanphier, 114.

80. Globe and Mail, August 8, 1969, A1.

81. LAC, RG 25, Volume 8560, file 20-1-2-CZECH, Political Affairs - Policy\&Backgd, Part 5. Oct.68-Apr.69. In early 1969, there was a furious debate in the media and the House of Commons after some Czech dentists complained 
that they weren't able to practice in Canada because the governing professional bodies refused to acknowledge their credentials. The government was accused of deceit in encouraging the dentists to move here despite the fact they couldn't practice. After a few weeks however, the government intervened on behalf of the refugees and furor died down.

82. Whitaker, Double Standard, 218.

83. LAC, RG25, External Affairs, Series A-3-c, Volume 9013, file 20-CZECH-2-1, Political Affairs - Reports and Statistics - Periodic.

84. Traditional views of exile and refugees emphasize that one of the distinguishing characteristics of this state, vis-à-vis, economic migration, is that exile is temporary. Refugees yearn to return home. See Howard Adelman, ed., Refuge or Asylum: A Choice for Canada (Toronto: York Lanes Press, 1990).

85. Globe and Mail, September 16, 1968, A1.

86. Here I take issue with Gerald Dirks, who has described the Canadian response to the refugees of 1956, 1968, and 1981 as largely motivated by foreign policy considerations. He declares that Canada relaxed its regulations because as a "member of the Western alliance and an ideological foe of the Soviet Union, wished to embarrass Moscow and its allies by welcoming their nationals who sought a more satisfying way of life under a different sort of political system." See Gerald Dirks, "Asylum Policy in Canada: A Brief Overview," in Refuge or Asylum: A Choice for Canada, 94.

87. While the assistance is perhaps not as altruistic as some scholarly analyses suggest (for the Hungarian refugees were also selected on the basis of their employability and potential to adapt to Canadian society), it is nevertheless a proud moment in the history of Canadian immigration efforts.

88. Jack Pickersgill, My Years with Louis St. Laurent: A Political Memoir (Toronto: University of Toronto Press, 1975).

89. Globe and Mail, January 4, 1969, A1.

Laura Madokoro is a 2009 Trudeau Scholar and Ph.D. Candidate in the Department of History, University of British Columbia. This paper began as an assignment for a research seminar at the University of British Columbia. The author thanks Dr. Tamara Myers and Patrick Slaney for constructive comments on early drafts and two anonymous reviewers for more recent suggestions. The author also thanks Mike Molloy of the Canadian Immigration Historical Society for his invaluable assistance. Research was funded by support from the Department of History, University of British Columbia. 